\title{
notas sobre o
} romance brasileiro

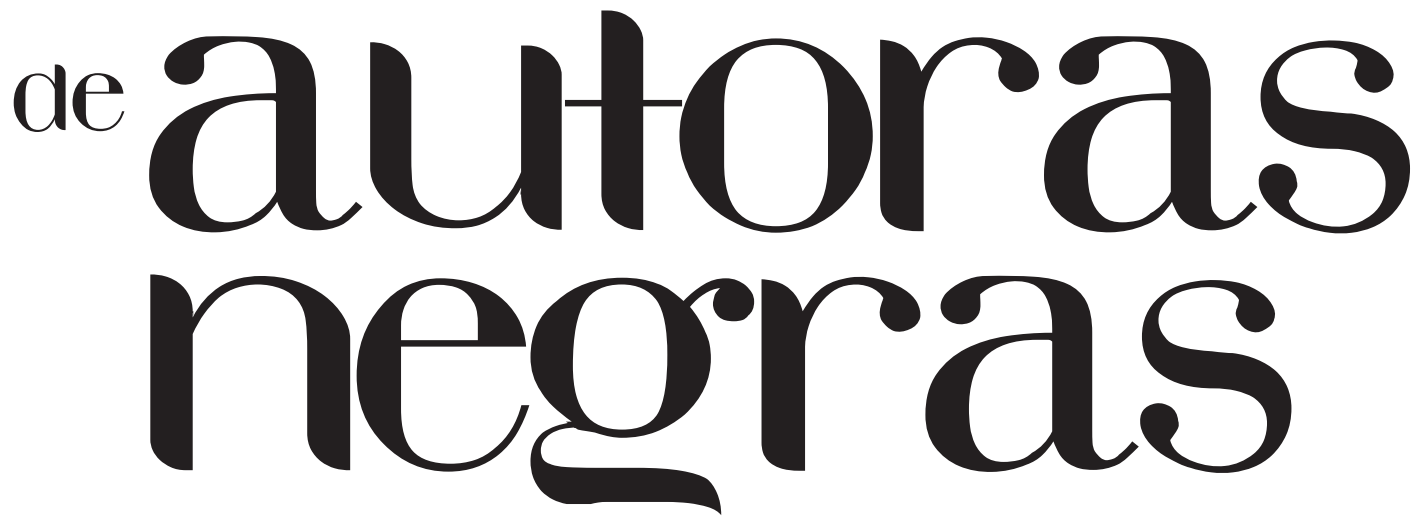

Fernanda Rodrigues de Miranda*

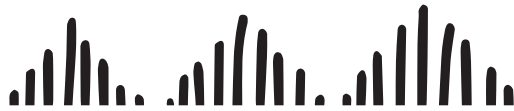

46
Doutoranda em Letras, área de Estudos Comparados de Literaturas de Língua Portuguesa - USP. E-mail: fernanda.miranda@usp.br. Artigo recebido em 18/11/2017 e aprovado para publicação em 04/04/2017.

\section{Resumo}

Como escritoras negras constituem sua voz autoral no romance? Abordaremos a questão a partir da leitura de Úrsula (1859), Um defeito de cor (2006) e As mulheres de Tijucopapo (1982), romances escritos por autoras negras em diferentes momentos da história. No texto de Maria Firmina dos Reis a autoria negra se constitui através do ponto de vista interno impresso no discurso; Ana Maria Gonçalves ficcionaliza seu lugar autoral, mesclando a voz narrativa com a de Luiza Mahin. Por fim, Marilene Felinto rejeita categorias enunciativas socialmente delimitadas. 


\section{Palavras-chave}

escritoras negras; romance; Ana Maria Gonçalves; Maria Firmina dos Reis; Marilene Felinto

\begin{abstract}
How do black women writers develop their own writing voice in a novel? This question will be discussed by focusing on three novels written by Black Brazilian women in different historical epochs: Úrsula (1859) by Maria Firmina dos Reis, As mulheres de Tijucopapo (1982) by Marilene Felinto and Um defeito de cor (2006) by Ana Maria Gonçalves. In Maria Firmina dos Reis's text, the Black author is constituted through the point of view presented in her discourse; Ana Maria Gonçalves fictionalizes her authorship bymixing the narrative voice with that of Luiza Mahin. Finally, Marilene Felinto rejects enunciative categories that are socially constructed.
\end{abstract}

\section{Keywords}

Black women writers; novel; Ana Maria Gonçalves; Maria Firmina dos Reis; Marilene Felinto

\section{Maria Firmina dos Reis: voz matricial}

A inscrição autoral negra feminina no romance brasileiro tem seu primeiro registro no contexto do romantismo, em pleno século XIX escravocrata, com o surgimento de um texto matricial para a literatura brasileira. Publicado no ano de 1859, Úrsula, de Maria Firmina dos Reis, é um romance precursor não apenas pela primazia histórica, mas principalmente pelo ponto de vista interno impresso à obra.

Conterrâneo da autora, o maranhense Gonçalves Dias escreveu os primeiros poemas em torno do negro: Meditação e $A$ escrava, publicados em 1846. Em prosa, o primeiro folhetim a tratar do tema da abolição dos escravos foi $O$ Comendador, lançado em 1856, por $\mathrm{Pi}$ nheiro Guimarães. Eram os passos inaugurais da ficção em terras nacionais, junto às obras publicadas no Rio de Janeiro, de autores como Joaquim Manuel de Macedo, Manuel Antonio de Almeida e o primeiro José de Alencar. Na mesma ocasião do surgimento de Úrsula, no ano de 1859, a Tipografia Fluminense de Paula Brito lançava outra obra paradigmática para a literatura brasileira: Primeiras trovas burlescas de Getulino, de autoria do escritor, intelectual e abolicionista Luiz Gama primeiro autor a se autoenunciar negro no Brasil. Ainda nesse mesmo ano, de mãos femininas, saía D. Narcisa de Villar, obra da catarinense Ana Luisa de Azevedo, obscurecida pela historiografia literária.

Diferentemente do que acontecia em outros territórios coloniais europeus, toda e qualquer atividade de imprensa, como publicação de jornais, panfletos e livros, foi proibida no Brasil até a chegada da família real, em 1808. Desse modo, a enumeração das datas dessas obras não apenas indica a coadunação de um campo literário inicial, mas demonstra o quanto Maria Firmina dos Reis foi uma intelectual prógona, pois além de publicar um romance em uma época em que pouquíssimas mulheres eram alfabetizadas ${ }^{1}$, obteve reconhecimento em vida, escreveu intensamente para jornais do período e foi a primeira professora efetiva a integrar oficialmente os quadros do magistério maranhense, função que ocuparia até o início de 1881, quando se aposenta e funda, no vilarejo de Maçaricó, a primeira escola mista e gratuita do país (MORAIS FILHO, 1975), que funcionou até 1890.

Não obstante tais feitos, seu lugar de pioneira do romance de autoria feminina foi objeto de disputa entre críticos e historiadores da literatura ${ }^{2}$, sugerindo, do nosso ponto de vista, a dificuldade da crítica em assumir, ou aceitar, que tal lugar pudesse pertencer a uma mulher afrodescendente. Todavia, além da relevância de sua primazia na história da autoria feminina no país, são os elementos textuais constitutivos do enredo de 
Úrsula que o tornam uma obra paradigmática dentro do contexto do século XIX.

A despeito da obra que produziu e da circulação que obteve, a historiografia parece não ter registrado imagens nos quais índices de corporeidade sustentem a referencialidade negra da escritora. Somando-se a isso, diferente de seu contemporâneo Luiz Gama, em Maria Firmina dos Reis não encontramos a autoinscrição negra articulada pela primeira pessoa do discurso. De modo que a autoria negra se formaliza no romance a partir de seus próprios elementos narrativos: 1) a elaboração do discurso abolicionista, através da 2) construção de personagens negros constituídos a partir de suas subjetividades.

À altura do meio século XIX, noções abolicionistas emergiam nos círculos intelectuais e políticos país afora. Surgiam em leitores que devoraram A cabana do pai Tomás, best-seller de Harriet Beecher Stowe publicado nos Estados Unidos em 1852, traduzido e lançado em Portugal no ano seguinte, porém, com diversas intervenções editoriais no texto, que atenuavam as expectativas sociais originais do romance, substituindo a urgência do abolicionismo de Stowe por uma interpretação gradativa, que permitia aos leitores conceber o fim da escravidão num futuro bem mais longínquo no universo lusófono (FERRETTI, 2016). De fato, ideias abolicionistas circulavam intensamente em jornais e salões literários, mas muitas vezes traduziam pontos de vista pouco preocupados com a libertação dos escravizados, envolvidos, antes, com a libertação da classe proprietária do trabalho compulsório para o livre crescimento da produção capitalista.

Diversos romances engajados com a campanha abolicionista veiculavam uma visão do escravo como ingênuo, infantilizado, fiel; outros o apresentavam como traiçoeiro, corrompido e animalizado, de convívio nocivo aos brancos. Em suma, nem sempre ideias aboliciocação "abolicionista" estavam, por exemplo, romances

como As vítimas-algozes: quadros da escravidão (1869), de Joaquim Manuel de Macedo, autor de A Moreninha (1844), obra que inaugura o romantismo brasileiro. Moreninha, evidentemente, não é marcador racial, pois a heroína Carolina representa perfeitamente o padrão de feminilidade que estava de acordo com o ideal amoroso romântico e as normas sociais vigentes no período. A questão racial, contudo, permeia a trajetória de Joaquim Manuel de Macedo como um todo. No prefácio de As vítimas-algozes, ele explica que "é preciso pintar o quadro do mal que o escravo faz de assentado propósito ou às vezes involuntária e irrefletidamente ao senhor". Nessa obra o autor constrói um autêntico tratado antiescravo, que se afirma antiescravista, defendendo a necessidade de acabar com a escravidão no Brasil, pois esta estava colocando em alto risco a segurança moral da família branca patriarcal.

Princípios abolicionistas também geraram $A$ escrava Isaura (1875), de Bernardo Guimarães, romance publicado 13 anos antes da promulgação da Lei Áurea de 13 de maio de 1888, e que apresenta o maior paradoxo da campanha de abolição da escravidão, pois assume a impossibilidade de construir uma heroína romântica negra e apresentá-la à sociedade do século XIX. O texto parte da premissa de que seria incompatível com o imaginário dessa época propor equivalência entre beleza, pureza, inocência e negritude, por isso a protagonista, ainda que escrava, precisava ter "a tez como o marfim do teclado".

Em meio a tantas ideias em torno do cativeiro, o real momento de inflexão da literatura abolicionista brasileira é inaugurado de fato com Úrsula, dado que o ponto de vista do romance projeta as personagens africanas e afrodescendentes como sujeitos - e não meros objetos da instituição escravidão. Difere, assim, da representação comum do negro, que só aparecia na escrita de autores brancos como escravo - como homem-metal, homem-mercadoria, homem-moeda. Em síntese, contrapondo-se às imagens e representações que o século XIX produziu em torno de homens e mulheres negras, Úrsula é um 
romance único: funda uma imagética nova para o tratamento de personagens negras na tessitura literária.

Diferente dos romances de Ana Maria Gonçalves e Marilene Felinto observados neste artigo, Úrsula é narrado em terceira pessoa. Uma voz narrativa onisciente que nos conduz pelos pensamentos das personagens, por suas memórias e concepções. O enredo é constituído por múltiplas histórias justapostas: ora o foco está nos dramas de Tancredo, ora repousa na cama da convalescente Luisa B., ora nos medos e angústias de Úrsula. Contudo, a voz da narradora assume uma perspectiva, um ponto de vista diretamente alinhado à experiência negra.

A negação da ordem social escravocrata é articulada no romance subjazendo o longo discurso, em primeira pessoa, de uma mulher africana envelhecida falando de/por si mesma. Lugar de fala qualificado - porque agenciado pelo sujeito da experiência escrava - na qual a personagem inverte a concepção hegemônica de civilização ao apontar que bárbaros eram os europeus. "Vou contar-te o meu cativeiro". Com esse enunciado performativo tem início a fala extensa que a personagem Susana direciona a Túlio, mas que a autora reporta à sociedade da época como um todo, descrevendo pela voz da personagem a dor da travessia no navio negreiro, o desenraizamento, as violências, os afetos, a saudade.

Maria Firmina dos Reis estava dialogando de forma crítica com o seu próprio presente - histórico e literário. Histórico, porque publicado durante a escravidão, seu romance introduz uma perspectiva na qual "o negro é o parâmetro de elevação moral" (DUARTE, 2004, p. 273), e os europeus, agentes do escravismo, são os "bárbaros". Literário, porque inserido no romantismo, se isenta do "instinto de nacionalidade", como nomeou Machado de Assis, deixando a "cor local" para segundo plano; ressaltando a vinculação afetiva do africano à sua pátria, em contraposição à ausência de qualquer pulsão nacionalista impressa nas personagens brancas.
Assim, a constituição da nacionalidade brasileira, grande paradigma romântico agenciado de forma intensa na literatura que circulava no período, não é uma questão aparente no texto da autora maranhense, visto que não há investimento explícito na busca de construção da nação e do ser nacional. A razão para isso está exatamente no fato de que o texto investe na escrita da subjetividade de pessoas negras escravizadas, as quais não estavam inseridas no projeto de nação gestado àquela altura. Em consequência disso a alforria jamais poderia ser tomada como sinônimo de liberdade, pois um negro nunca seria livre em um país de escravos.

Maria Firmina dos Reis articula a sua enunciação negra a partir da própria construção discursiva do romance: em Úrsula, o negro possui características morais elevadas, como a coragem, a lealdade e a bondade; tem vontade própria, tem lugar de fala e respeita seus próprios códigos de conduta. A partir do ponto de vista da mulher africana escravizada (personagem Susana), o texto engendra uma concepção profunda de liberdade, projetada na memória da experiência na terra de origem. Com base nas características das personagens e nos diálogos de Úrsula, Reis articula um discurso abolicionista que desmonta a concepção do escravizado comum nos discursos de seu tempo - considerando que o século XIX é também o século da emergência da raça como paradigma nuclear de naturalização das diferenças, sustentado em teorias e postulados científicos ${ }^{3}$. Em ruptura à visão hegemônica sobre os africanos e descendentes no século XIX, o negro é representado no romance como "pessoa", como agente portador de memórias vivas da experiência de antes da diáspora, sujeito de afeto imbuído de princípios éticos. Esses elementos dão ao romance de Maria Firmina dos Reis a materialidade de uma enunciação negra singular para o século XIX. 


\section{Um defeito de cor: voz espiral do tempo}

Um defeito de cor (2006) é uma obra cujo empenho incide na releitura do tempo da escravidão, reescrevendo o passado colonial através do protagonismo da experiência negra diaspórica. Resultado de ampla pesquisa da autora, um romance de história das mentalidades, modalizado como escrita da memória, em que relembrar não é somente retorno, mas um ato de contraefetuar a história nacional.

A escrita da obra responde à busca inicial da autora acerca de um episódio da história do Brasil ainda hoje pouco conhecido: a Revolta dos Malês, ocorrida na Bahia, em 1835, e liderada por Luiza Mahin. Assim tangenciando um prisma comum a diversas obras da literatura negra brasileira -, do empenho de interpelar as lacunas do discurso histórico nasce a ficção. Ficção que já começa no prólogo, onde a autora apresenta o romance aos leitores como livre tradução de um manuscrito autobiográfico escrito em português arcaico por Kehinde, uma africana que viveu a experiência escrava e recebeu o nome de Luiza no Brasil.

Nesse prólogo, Ana Maria Gonçalves explica que "apenas alguns trechos" do livro são ficção e foram escritos para cobrir partes perdidas do "original". Dessa maneira, o paratexto do livro atribui o conteúdo da narrativa a um manuscrito "originário" imaginário. Por conseguinte, a autora formaliza, nesse engenho, um ato de ficcionalização do próprio processo de composição do texto, pois o manuscrito jamais existiu de fato: é um constructo ficcional operante no ato de enunciação da autora, articulando uma ponte feita da mescla de sua voz à voz ficcionalizada de uma personagem histórica paradigmática - Luiza Mahin, a quem Luiz Gama elegeu como sua mãe. Através deste gesto performático, antes de adentramos nas linhas da trajetória da protagonista, o romance inscreve no discurso a potência do feminino negro, subvertendo narrativas oficiais nas quais a feminilidade negra esteve sempre à margem.

Atribuir à narrativa uma fonte externa e alheia à própria criação do autor é um recurso comum, utilizado, pelo menos desde o romantismo, a fim de conferir verossimilhança, autoridade e originalidade às obras. $\mathrm{A}$ partir de tal estratagema, o autor/narrador se exime da totalidade do conteúdo narrado, dividindo com outrem essa função. No caso de Ana Maria Gonçalves, a função deste expediente é iluminar o que tem sido silenciado, trazendo à superfície da memória o que foi obliterado pela história oficial. Assim, antes da primeira palavra da primeira pessoa que narra, a autora incorpora um pré-texto, enunciando os vestígios de outro sujeito e outro tempo. Deste modo, posto que "a ficção pode reivindicar um valor de verdade" (GOODY, 2009, p. 38), se constrói, no prefácio, uma categoria de verdade testemunhal que, através de memórias ficcionais, deslinda aspectos da História.

Um defeito de cor narra a trajetória de Kehinde desde os 8 até os 88 anos de idade. Oitenta anos, narrados em dez capítulos. A experiência da diáspora está no gesto que funda a primeira pessoa da narrativa, tem início quando Kehinde é capturada por mercadores de escravos na África e segue por todas as quase mil páginas da "maior obra escrita por uma afro-brasileira" (DUKE, 2016, p. 11).

A trajetória da protagonista, tomada como base referencial, é toda constituída no trânsito - desde a primeira infância no Daomé, até as experiências por diversas regiões do Brasil, voltando para outros lugares da África e retornando novamente pelo Atlântico, a personagem é constituída pelo signo da itinerância. Esse aspecto é de grande relevância, considerando que no continente africano o princípio da fronteira fixa foi uma imposição dos colonizadores europeus. Com efeito, invertendo o princípio da fronteira, a personagem promove uma "circulação de mundos" em seu trânsito intenso através de espacialidades, culturas, códigos, temporalidades e afetos, demarcando nesse movimento um fundamento observado em todo o livro: a itinerância como vértice para ler a tradição. 
A narrativa vai paulatinamente reinscrevendo o lugar de uma feminilidade negra que sai da condição de subalternidade ao acionar dispositivos de agência como, entre outros, o ato de nomear, destacado, por exemplo, na passagem em que Kehinde conta como batizou de Carolina a heroína do primeiro romance do romantismo brasileiro, A moreninha, de Joaquim Manuel de Macedo, autor que a certa altura se torna personagem da narrativa, e com funcionalidade específica, pois esse autor, como já dissemos, explorou fartamente o tema da escravidão em sua produção literária, acadêmica e didática. Macedo pode ser tomado como representante de uma linhagem de pensamento identificável em autores que constituíram suas premissas "praticando o alterocídio, isto é, constituindo o Outro não como semelhante a si mesmo, mas como objeto intrinsecamente ameaçador, do qual é preciso proteger-se, desfazer-se, ou que, simplesmente, é preciso destruir, devido a não conseguir assegurar o seu controle total" (MBEMBE, 2014, p. 16). É com essa linhagem de pensamento que o romance de Gonçalves também está dialogando.

A narrativa de Kehinde tem uma destinação: são cartas para Luiz, seu filho perdido, motivo maior de sua procura. Por isso, diante do "eu" enunciativo há um "você" irredutível, razão da saga da personagem. A ficção aqui novamente performatiza o real, colocando Luiz Gama - fundador do primeiro texto em que um autor se autoenuncia negro, ponto matricial da literatura negra brasileira - como a pulsão para a existência do texto, pois Kehinde escrevia para que seu filho pudesse conhecer sua história. Antes, a presença do autor abolicionista é invocada já no título do romance, que toma sua origem em uma citação de Gama.

O romance articula uma voz narrativa que dialoga em muitos aspectos com Úrsula: centrados no período da escravidão, ambos estão empenhados na focalização de experiências negras na diáspora, a partir do qual a História pode ser lida sob outras perspectivas. Nesse sentido, podemos ler nos dois romances o princípio de que "a escrita da história tem uma dimensão performativa, o objetivo passa de fato por escrever uma história que reabre, para os descendentes de escravos, a possibilidade de voltarem a ser agentes da própria história" (MBEMBE, 2014, p. 60). Assim, fraturando os mecanismos da racionalidade colonial, Maria Firmina, escrevendo no século XIX, posiciona-se como uma voz crítica ao seu tempo, marcado pela servidão. Ana Maria Gonçalves, produzindo no século XXI, reescreve o século XIX e a mentalidade nele operante, cujos vestígios incidem no presente.

Por fim, as obras têm em comum o fato de articularem a inscrição de vozes autorais negras, constituídas no âmbito interno do próprio texto. No caso de Firmina, embora tenhamos poucas informações biográficas sobre a autora, sabe-se que ela era "fruto do provavelmente incomum relacionamento amoroso entre uma portuguesa e um escravo africano" (CORREIA, 2013, p. 100). Não obstante, o romance finca um território de fala que não estava alinhado às proposições políticas de certa "visão mestiça" (SCHWARCZ, 2005, p. 12) em ascensão, e se contrapõe, em termos ideológicos, à enunciação adotada pela parcela mulata da sociedade, cujo posicionamento frente à escravidão se distanciava do corpo escravo e se concentrava na possibilidade de um branqueamento hipotético. Nesse sentido, a autoria negra não se associa apenas à condição racial da autora, mas a seu posicionamento político tal como ele emerge no interior da própria obra (DIOGO, 2016, p. 26).

Por seu turno, o romance de formação Um defeito de cor é também uma obra de formação da identidade racial da autora, pois, tal como ela mesma afirma, através da escrita do texto passou a pensar a si como uma mulher negra, conforme se lê na citação abaixo:

Nascida de mãe negra e pai branco, sou daqueles seres cujo corpo e mestiçagem foram e continuam sendo usados para defender o que não se sustenta: a inexistência de racismo. Racismo

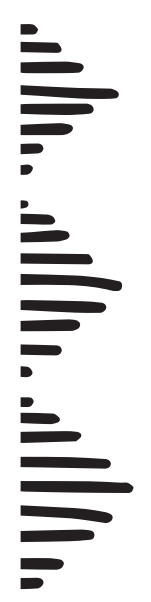

51 
que está na própria raiz da minha existência ao ter sido inventado para justificar o envio de corpos negros como força motriz na construção do Mundo Novo. Tive então, como mestiça, o privilégio de não ter que me pensar negra, de não ter que me pensar como fruto de um projeto de dominação até bastante tarde na vida, quando o livro já começava a fazer parte dela. Foi o meu mapa. Foi o meu guia por entre as ruínas internas de onde brotavam vozes, histórias, segredos, lamentos, risos, resquícios de outros mapas cujas línguas e símbolos fui aprendendo a interpretar (GONÇALVES, 2017, p. 3).

Por razões diversas, conforme veremos, a escrita como guia, como mapa, como a maneira possível de acertar as contas com o passado (histórico e particular), pode ser observada também no romance de Marilene Felinto, para o qual voltamos a análise neste momento.

\section{As mulheres de Tijucopapo: tensionando lugares da voz}

Diferente dos romances de Reis e Gonçalves, Mulheres de Tijucopapo (1982), livro de estreia da escritora pernambucana Marilene Felinto, articula uma voz narrativa dilacerada, isenta de certezas, em crise, em processo. Rísia, personagem protagonista do romance, é uma mulher negra, migrante, nordestina, que inicialmente não nutre pertencimento prévio a nenhum grupo, embora projete uma comunidade de destino.

O coletivo se perdeu, assim como todos os seus territórios de afeto, mas ela está partindo rumo ao solo das mulheres de Tijucopapo - que remete historicamente a uma pequena vila pernambucana onde, no século XVIII, mulheres lutaram contra os invasores holandeses e saíram vitoriosas -, tomadas como símbolo e potência de liberdade aos olhos da personagem: uma possibilidade aguerridas - representando o oposto ao entendimento que nutria sobre sua mãe, sua matriz. Assim como o de Gonçalves, o romance de Marilene Felinto se inscreve na poética da memória, que para Lúcia Helena Vianna (2004) é característica de grande parte da produção narrativa de autoria feminina no Brasil e tem sido a tônica sobretudo da escrita da diáspora contemporânea. Mas, diferente de Kehinde, as memórias de Rísia vêm em convulsão, diluindo as fronteiras entre passado e presente, isentando-se da linearidade narrativa com o propósito de traduzir as fraturas de um sujeito cuja identidade está em vívido processo.

A narrativa contada por Rísia é inteiramente marcada pelo verbo "partir": parte do abrasivo Recife de sua infância para a promessa de uma vida feliz representada pela quimérica São Paulo; depois, retraçando o roteiro migrante, parte da experiência de silêncio e isolamento vivida em São Paulo para a perspectiva utópica de uma coletividade feminina guerreira localizada em Tijucopapo; parte da gagueira - resultado da falta de afeto, da violência e da dificuldade de ler(-se) (n)a grande cidade - para a conquista da palavra, que muitas vezes sai raivosa.

O romance é uma narrativa de descentramento do sujeito diante da língua materna, da sua biografia, da narrativa de fundação de sua identidade. Em busca de novas possibilidades de ser uma mulher diferente das que foram sua mãe e sua tia, Rísia é "uma mulher indo sozinha pela estrada" (FELINTO, 1992, p. 55). No entanto, sua condição de forasteira ultrapassa fronteiras territoriais e se instaura inclusive na linguagem: "Em São Paulo eu só encontrei palavras em língua estrangeira. Ou numa mudez impressionante. Em São Paulo eu quase perdi a fala" (FELINTO, 1992, p. 81), de modo que a personagem elege o inglês como seu idioma possível, pois suas emoções e angústias não se faziam inteligíveis na língua pátria, era necessário traduzi-las em outra sonoridade: "Agora eu já não gaguejo mais, agora eu emudeço de 
vez ou falo direto em língua estrangeira. [...] Eu já fui uma verdadeira muda" (FELINTO, 1992, p. 57).

A trajetória da personagem vai da gagueira à condição de muda, passa pela escolha do inglês como possibilidade de falar - abrindo mão, portanto, do pressuposto imediato de que será compreendida -, e chega à vontade de contar a própria vida através de uma linguagem não alfabética: "Quero compor uma ária que saia música fina como as cordas do violão. Uma ária que seja a carta que escreverei quando chegar a Tijucopapo, a terra onde minha mãe nasceu. [...] Quero compor uma ária de amor que ecoe nas cavernas dessa montanha onde estou" (FELINTO, 1992 p. 85).

O processo complexo de agenciamento/gerenciamento da voz experimentado por Rísia toca em um ponto histórico nuclear da construção literária de autoras negras dentro do nosso contexto nacional, feito de silenciamentos discursivos sistemáticos ${ }^{4}$. Ponto tensionado por diversas autoras, esse processo aparece, por exemplo, de forma transversal na obra de Carolina Maria de Jesus, para quem a voz - sobretudo a voz - era agasaIho vital: num dia frio paulistano, ela escreveu no seu diário: "Hoje estou com frio. Frio interno e externo. Eu estava sentada ao sol escrevendo e supliquei, oh meu Deus! Preciso de voz" (JESUS, 1996, p. 152).

A transformação do silêncio em linguagem e em ação, tradução do título em inglês da poeta e pensadora feminista afro-americana Audre Lorde: "The transformation of silence into language and action", diz muito do difícil transcurso de reivindicação da fala para escapar da inexistência social.

In becoming forcibly and essentially aware of my mortality, and of what I wished and wanted for my life, however short it might be, priorities and omissions became strongly etched in a merciless light, and what I most regretted were my silences. Of what had I ever been afraid? To question or to speak as I believed could have meant pain, or death. But we all hurt in so many different ways, all the time, and pain will either change or end. Death, on the other hand, is the final silence. And that might be coming quickly, now, without regard for whether I had ever spoken what needed to be said. (...) And of course I am afraid, because the transformation of silence into language and action is an act of self-revelation, and that always seems fraught with danger (LORDE, 2007, p. 41, 42, grifos do original) ${ }^{5}$.

Depois de uma longa travessia que durou nove meses, após seu próprio dilaceramento através da dor e da presença da morte, Rísia assume a condição de (re)formular sua identidade. Nesse momento ela se imagina Maria Bonita, ou amazona destemida que planeja invadir a Avenida Paulista em busca das luzes que brilham lá para dependurá-las nos postes apagados das ruas de sua infância. Não se trata, contudo, da erupção de uma heroína. Antes, de um sujeito altamente reflexivo que reconhece a dor do abandono, da falta de pertencimento, das fronteiras socioculturais inerentes a uma sociedade desigual, e parte, qual caçadora de si, rumo à própria travessia. Uma narradora-protagonista que faz um doloroso inventário de sua vida, um acerto de contas com o passado.

É difícil até acreditar que serei capaz de ir até o fim. Pouca gente foi. E isso torna tudo mais árduo. Além de que, essa pouca gente que foi não deixou passos, uma trilha feita. Mas nenhuma trilha feita me serviria também. Devo abrir a cortes minha própria linha na mata, devo fazê-la eu só. Trilha nenhuma outra me serviria. $\mathrm{E}$ isso torna tudo mais árduo. $\mathrm{O}$ sol derrete sobre minha cabeça, minha pele 
escurece a mais e mais, chegarei negra em Tijucopapo [...]. (FELINTO, 1992, p. 94).

Se Kehinde e Susana articulam vozes irredutíveis na escrita de novos lugares de composição da experiência negra no período colonial, Rísia engendra uma voz lacerada, totalmente imersa no contemporâneo, pautada na exclusão, na fronteira, na violência, no confronto da alteridade - nos mecanismos ainda operantes do colonialismo. Entre os três romances, cercados de diferenças e aproximações, permanece em relevo a formalização estética da experiência social de indivíduos submetidos à consciência do tempo histórico - dito em outras palavras, mulheres negras rompendo, através do discurso literário, uma ordem social de negação de suas existências.

Quanto à autoria feminina negra, a escritora Marilene Felinto coloca questões interessantes para reflexão em torno do lugar de fala, pois rejeita lugares enunciativos socialmente posicionados. A respeito de seus posicionamentos quanto ao seu lugar autoral, isto é, de uma escritora negra, observem-se as proposições de Michel Foucault, para quem a obra literária passa, a certa altura do pensamento ocidental, a remeter à figura do autor e este, a ser um ponto de referência indissociável da mesma, uma ferramenta social de controle para o texto e para as suas expectativas, na mesma intensidade em que é passível de ser controlado externamente pelas forças sociais (SILVA, 2013). Entre as funções do autor, na virada do século XVIII para o XIX, Foucault afirma: "os textos, os livros, os discursos começaram efetivamente a ter autores na medida em que o autor se tornou passível de ser punido, isto é, na medida em que os discursos se tornaram transgressores" (FOUCAULT, 2000, p. 47). No caso de Marilene Felinto, o texto crava na boca de Rísia uma frase que bem poderia ser da autora: "Eu desconto com pedras. Jamais vou admitir que me definam" (FELINTO, 1992, p. 23). Apontando, assim, para um ponto de reflexão impor- assumido, ou não, publicamente e politicamente pelo autor, não pode resultar em um enquadramento prescritivo da escuta.

\section{Referências bibliográficas}

ASSIS, Machado de. Notícia da atual literatura brasileira. Instinto de nacionalidade. In: Obra Completa de Machado de Assis. Rio de Janeiro: Nova Aguilar, 1994. v. 3.

CORREIA, Janaína Dos Santos. O uso de fontes em sala de aula: a obra de Maria Firmina dos Reis (1859) como mediadora no estudo da escravidão negra no Brasil. Dissertação (Mestrado em História Social) - Universidade Estadual de Londrina, Paraná, 2013.

DALCASTAGNĖ, Regina. Literatura brasileira contemporânea, um território contestado. Rio de Janeiro: Editora da UERJ; Vinhedo: Horizonte, 2012.

DIOGO, Luciana Martins. Da Sujeição à subjetivação: a literatura como espaço de construção da subjetividade, os casos das obras Úrsula e A escrava, de Maria Firmina dos Reis. Dissertação (mestrado em Estudos Brasileiros) ? Instituto de Estudos Brasileiros, Universidade de São Paulo, 2016.

DUARTE, Eduardo de Assis. Maria Firmina dos Reis e os primórdios da ficção afro-brasileira. In: REIS, M. F. dos. Úrsula. Florianópolis: Editora Mulheres; Belo Horizonte: PUC-Minas, 2004. p. 265-281.

DUKE, Dawn. (Org.). A escritora afro-brasileira. Ativismo e arte literária. Belo Horizonte: Nandyala, 2016.

FELINTO, Marilene. As mulheres de Tijucopapo. 2. ed. Rio de Janeiro: Editora 34, 1992.

FERRETTI, Danilo José Zioni. A publicação de "A cabana do Pai Tomás" no Brasil escravista. Revista Varia Historia, -brasileira/negra/afro-descendente, pois o lugar de fala 
Belo Horizonte, v. 33, n. 61, p. 189-223, jan/abr 2017. Disponível em: <http://www.scielo.br/pdf/vh/v33n61/1982-4343vh-33-61-00189.pdf>. Acesso em: 12 mar. 2017.

FOUCAULT, Michel. O que é um autor? São Paulo: Paisagens, 2000.

GONÇALVES, Ana Maria. Um defeito de cor. Rio de Janeiro: Record, 2014.

Uma ficção à procura de suas metáforas. Suplemento Pernambuco, n. 132, fev. 2017. Disponível em: <http://www. suplementopernambuco.com.br/edi\% $\mathrm{C}_{3} \% \mathrm{~A} 7 \% \mathrm{C}_{3} \% \mathrm{~B}_{5}$ es-anteriores/67-bastidores/1783-uma-fic $\% \mathrm{C}_{3} \% \mathrm{~A}_{7} \% \mathrm{C}_{3} \% \mathrm{~A}_{3} \mathrm{O}-$ -\% 3 C $\%$ Ao-procura-de-suas-met $\% \mathrm{C}_{3} \%$ A f foras.html> Acesso em: $1^{\circ}$ mar. 2017.

GOODY, Jack. Da oralidade à escrita - reflexões antropológicas sobre o ato de narrar. In: FRANCO, Moretti (Org.). A cultura do romance. Tradução Denise Bottmann. São Paulo: Cosac e Naify, 2009.

JESUS, Carolina Maria de. Meu estranho diário. Org. José Carlos Sebe Bom Meihy e Robert Levine. São Paulo: Xamã, 1996.

LOBO, Luiza. Maria Firmina dos Reis. In: DUARTE, Eduardo Assis (Org.). Literatura e afrodescendência no Brasil: antologia crítica. v. 1: precursores. Belo Horizonte: Editora UFMG, 2014.

LORDE, Audre. Sister Ousider. Essays and Speeches. Berkeley, CA: Crossing Press, 2007.

MBEMBE, Achille. Critica da razão negra. Trad. Marta lança. Lisboa: Antígona, 2014.

MENDES, Algemira de Macêdo. A escrita de Maria Firmina dos Reis na literatura afrodescendente: revisitando o cânone. Lisboa: Chiado, 2016.
MORAIS FILHO, José Nascimento. Maria Firmina dos Reis, fragmentos de uma vida. São Luís: Governo do Estado do Maranhão, 1975.

REIS, Maria Firmina dos. Úrsula. Organização, atualização e notas por Luiza Lobo. Rio de Janeiro: Presença; Brasília: INL, 1988.

SCHWARCZ, Lilia Moritz. O espetáculo das raças. Cientistas, instituições e a questão racial no Brasil (1870-1930). São Paulo: Cia das Letras, 2005.

SILVA, Mário Augusto Medeiros da. A descoberta do insólito: literatura negra e literatura periférica no Brasil (1960-2000). Rio de Janeiro: Aeroplano, 2013.

VIANNA, Lúcia Helena. Poética Feminista - Poética da Memória. In: LIMA, Claudia de; SCHMIDT, Simone Pereira (Orgs.). Poéticas e Políticas Feministas. Florianópolis: Mulheres, 2004.

\section{Notas}

1 Embora o Maranhão à época da autora fosse considerado a "Atenas brasileira", devido a seu elevado potencial cultural e sua circulação econômica, o ensino era precário, como era em todo o Império. Em 1859, quando o romance é publicado, havia 2.115 meninos e 433 meninas matriculadas no ensino primário (MENDES, 2016, p. 30). Neste cenário de desigualdade de gênero no acesso à instrução, incluímos o fato de que Maria Firmina dos Reis acessou o conhecimento de forma autodidata, enquanto os escritores românticos seus contemporâneos em geral cumpriam sua formação em Coimbra, Lisboa ou Paris.

2 No capítulo dedicado a Maria Firmina dos Reis na Antologia Literatura e Afrodescendência no Brasil: precursores, Luiza Lobo resume bem a questão: "Ainda persiste, por vezes, a dúvida sobre o pioneirismo de Maria Firmina 
com romance Úrsula. No passado, alguns críticos entenderam que a primeira escritora de romance brasileira era Teresa Margarida da Silva e Orta ou Horta, irmã do filósofo Matias Aires. Compreende-se o desejo de recuar a gênese do romance brasileiro de autoria feminina até o final do século XVIII. No entanto, Teresa Margarida se mudou com a família portuguesa para Portugal quando contava 5 anos de idade, sem mais retornar ao Brasil. Além disso, o tema ilustrado de seu romance epistolar As Aventuras de diófanes (1777), que se inspira em A viagem de Telêmaco, de Fénelon, tem suas raízes no contexto cultural europeu. Desse modo, a autora faz parte da literatura portuguesa, fato que já foi suficientemente comprovado. Também o nome de Ana Eurídice Eufrosina de Barandas foi aventado como a primeira romancista feminina. No entanto, $O$ Ramalhete; ou flores escolhidas no jardim da imaginação é uma miscelânea de contos crônicas e pensamentos, mas não um romance. Outro obstáculo, também superado, que dificultou o estabelecimento de Maria Firmina dos Reis como a primeira mulher romancista brasileira foi a hipótese que sugeriu o nome da rio-grandense-do-norte Nísia Floresta. Esta autora é, no entanto, tradutora e ensaísta. Escreveu obras didáticas curtas e crônicas sobre o Rio de Janeiro, além de dois livros de viagem, um deles de forma epistolar." (LOBO, 2014, p. 112-113).

3 Em 1871, com a implementação da Lei do Ventre Livre, o desmantelamento do escravismo e a construção de instituições assentes em uma igualdade política, a hierarquia social vai encontrar refúgio e apoio ideológico em um discurso racial. Discurso este, como mostra a obra $O$ espetáculo das raças - cientistas, instituições e questão racial no Brasil (1870-1930), fomentado nos "jovens centros brasileiros de saber histórico, jurídico e médico" (SCHWARCZ, 2005, p. 47).
4 Sobre estes silenciamentos, especificamente no romance, é fundamental a pesquisa de Regina Dalcastagnè (2012), publicada sob o título Literatura brasileira contemporânea, um território contestado.

5 "Ao tomar forçadamente consciência de minha própria mortalidade, do que desejava e queria de minha vida, durasse o que durasse, as prioridades e as omissões brilharam sob uma luz impiedosa, e do que mais me arrependi foi de meus silêncios. $O$ que me dava tanto medo? Questionar e dizer o que pensava podia provocar dor, ou a morte. Mas, todas sofremos de tantas maneiras todo o tempo, sem que por isso a dor diminua ou desapareça. A morte não é mais do que o silêncio final. E pode chegar rapidamente, agora mesmo, mesmo antes de que eu tenha dito o que precisava dizer. [...] E, certamente tenho medo, porque a transformação do silêncio em linguagem e em ação é um ato de autorrevelação, e isso sempre parece estar cheio de perigos" (Tradução livre). 